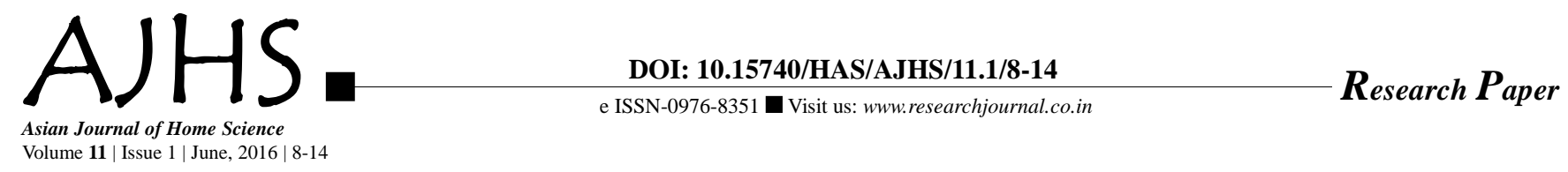

\title{
Comparison of parenting stress among normal and developmentally challenged children
}

\author{
NARMADA HIDANGMAYUM AND PUSHPA.B. KHADI
}

Received: 04.01.2016; Revised: 17.03.2016; Accepted: 03.04.2016

See end of the paper for authors' affiliations NARMADA HIDANGMAYUM Department of Human Development and Family Studies, Rural Home Science College, University of Agricultural Sciences, DHARWAD (KARNATAKA) INDIA Email : hnarmada@gmail.com
ABSTRACT : The maternal and paternal parenting stress of normal and developmentally challenged children was studied among the parents of normal, mentally challenged and hearing impaired children. Participants were 314 fathers and 341 mothers of children under the age group of 5 to 15 years. Parenting stress was assessed with Abidin's (1995) "Parenting stress index- short form". Frequency, percentage, t-test and one way ANOVA were used for the analysis. The results revealed that there was significant difference between parents of normal and developmentally challenged children on parenting stress wherein higher percentage of parents were in clinically significant category among mentally challenged and hearing impaired than normal group. Paternal and maternal parenting stress did not differ significantly.

KEY WORDS: Parenting stress, Mentally challenged, Hearing impaired, Normal children

- HOW TO CITE THIS PAPER : Hidangmayum, Narmada and Khadi, Pushpa.B. (2016). Comparison of parenting stress among normal and developmentally challenged children. Asian J. Home Sci., 11 (1) : 814, DOI: 10.15740/HAS/AJHS/11.1/8-14. 